\title{
DAUGHTER MAIDEN MAIDSERVANT: DYNAMICS OF SEMANTIC SHIFT FROM Continental Celtic to Insular Celtic Vocabulary ${ }^{*}$
}

\author{
TATYANA A. MIKHAILOVA
}

\section{Introduction}

The history of Irish language has been thoroughly explored as much as its phonology, morphology and syntax - in their transition from Old Irish to Middle Irish and to its modern state - are concerned. However, the language vocabulary has been largely ignored, ${ }^{1}$ while it is the vocabulary evolution that provides the basis for the glottochronological studies, based on lexicostatistics. This is understandable, since vocabulary is the least systematic part of language and, therefore, the most challenging when one faces the task of structural description; however, lexical changes reflect changes in the society. From this viewpoint, one of the most interesting lexical-semantic groups is kinship terminology, which is normally quite distinct and compact yet having marked ways of evolution. This minor piece of our research will encompass a single sememe of 'daughter' in Celtic languages.

\section{Reflexes of IE 'daughter' in Celtic}

It has been commonly accepted that cognates of the proto-Indo-European word for 'daughter' $\left(*\right.$ dhugH (Szemerenyi 1977: 21) or *dhug $\left(h_{2}\right)$-tวr (Mallory, Adams 2006: 472)) survive in many later languages save for Albanian, Italic and Celtic. ${ }^{2}$ Its only reflex is thought to be the Old Irish der 'daughter, girl', a shortened form of the Indo-European stem surviving only in compound words (O'Brien 1956: 178), "an allegro-form" (Matasović 2009: 110). Typically, Der- (also found in such forms as Dar-, Tar-, Ter-) is the first part of a compound name in which the second part appears in a genitive form, so it may be interpreted as 'daughter of'. However, such compounds are never used as patronymics, but rather as

\footnotetext{
* This work represents a part of collective research project 'Text in Interaction with Social Cultural Environment', supported by the Russian Academy of Sciences.

${ }^{1}$ Save for studies describing loanwords (of either Scandinavian, English or Anglo-Norman origin).

${ }^{2}$ See also, for the possible Indo-European origin of Middle Persian duxt 'princess' in (Kullanda 2002: 92), while in Mongolic the word for 'daughter, girl, princess' is ökin (Rykin 2009: 89).
} 
proper names, such as Derfhinn, Der(b)forgaill, Derluga, Daróma, Derfiled etc. While most of them are commonly understood as derivations from theonyms, Derfiled means 'daughter of a poet', but, surprisingly, in Irish sources the latter name appears as belonging to males. At least two instances of male saints bearing this name are given by Donnchadh Ó Corrain and Fidelma Maguire in their book on Irish names (Ó Corrain, Maguire 1990: 71). Sometimes, however, der-may appear as an isolated lexeme, in such expressions as Der gréine ('daughter of the Sun', e.g. 'dew' (LEIA-D 53)) or alone. The 'obscure bardic language' yields such an example as mór ndear i. mór mban 'many ndear, i.e. many women'. This case makes the interpretation of semantics and etymology of dermore problematic. In the surviving compounds it may well be interpreted as the 'wife of', and Der gréine might be understood as the 'solar woman'. On the other hand, Cormac mac Cuilennáin in the early $10^{\text {th }}$ century glossed der- as ingen 'girl, daughter, young woman' (Meyer 1913: 41). Perhaps this lexeme is not unrelated to Old Irish ander 'girl, young woman', glossed in the same work by Cormac as ander .i. ben i. ní der i. ní hingen (Meyer 1913: 9), and can be translated as 'Ander, i.e. a woman, i.e. not a girl (der), i.e. not a daughter'. Cormac's popular etymology is improbable, since in Goidelic the Indo-European prefixal negator would consistently becomes in-, rather than an-, which in fact is an emphatic prefix of unclear etymology, unrelated to negation. Welllearned in Latin, Cormac, however, lacked understanding of native Celtic language structures, so his etymology, cited by Joseph Vendryes, can hardly be other than a bizarre one. Nor the parallel to Welsh anneir 'heifer', suggested by Vendryes (LEIA-A 76), seems phonetically plausible: Brittonic languages, unlike Goidelic, would not tend to assimilate consonant clusters. However, the semantic transition between 'heifer' and 'girl' is not infrequent and well attested in the Irish saga tradition. Moreover, the link between the words for 'son/boy' or 'daughter/girl' and those denoting animal youngsters is by no means uncommon, though the exact way of semantic transition cannot be identified. For instance, some Russian dialects use the word dochka (which the literary norm has for nothing other than 'daughter') for 'young sow' (Trubachev 2006: 57). Modern Russian slang uses tyolka ('heifer') for 'teenage girl, young woman'. Compare also Old Irish suth 'litter', deriving from a Proto-Indo-European word for 'son' (LEIA-RS 205).

In the early 1970s, a Gaulish lead tablet dating back to the first century A.D. was found in Larzac, France, which added to the known vocabulary of Continental Celtic a new lexeme, duxtir, with the possible meaning of either 'daughter' or 'female disciple, female foster-child' 
('jeune fille initiée', in (Lejeune 1985: 133); see also (Sims-Williams 2007: 3)). Anyway, there is little disagreement on the word's etymology.

\section{Gaulish geneta vs. Old Irish ingen}

Maurice Lejeune's suggestion that duxtir must have had a narrower sense than just 'a girl' is apparently supported by the fact that, in Gaulish, the broader meaning of 'a girl, daughter (?), female person' is normally represented by derivations from another IE stem, * $\dot{g} e n h_{1}$ 'to generate' (IEW 373 ff.): geneta, genata, gneta, nata (Delamarre 2003: 177, 181); compare also Oscan genetaí 'daughter'.

This lexeme is an adjectival of IE * $\hat{g} e n h_{1}-t-\bar{a}(* \hat{g} e n-$ 'to bear, generate', (Matasović 2009, 157)), formed by the -t-affix and, in Gaulish, well-attested also in the masculine form, both in personal names (Meddugnatus, Eposo-gnatus etc.) and separately, with a probable meaning of 'boy' or 'son'. A closer look at Gaulish inscriptions brings us to a stunning conclusion: the use of the feminine form is limited to a single particular kind of source, that is, inscriptions on loom-weights (for more on this class of archaeological objects, see (RIG 317)). Loom-weights were specifically feminine attributes, and the tradition of inscribing them with playful phrases, as well as the whole epigraphic tradition of Gaul, dates back to the late Roman Empire. Loom-weight inscriptions are also not uncommon among archaeological finds from Medieval Scandinavia and Russia. This kind of finds with Latin inscriptions occurs as commonly in Gaul as in late Rome, and, just as commonly, they bear a word with a meaning of 'female person'. Here are some examples: SALVE TU, PUELLA; AVE DOMINA; SALVE, DOMINA; SALVE SOSOR; AVE VALE BELLA TV (RIG 318). Compare some Gaulish parallels (numbering after RIG, translation being conjectural):

L-112: NATA VIMPI / CVRMI DA 'lovely girl, give me beer'

L-114: GENETA / VIS CARA 'girl, be sweet'

L-115: M (N?)ATTA DAGOMTA / BALINE E NATA 'girl good ... girl'

L-119: MONI GNATA GABI / BVDDVTTON IMON 'come girl, take my small...'

L-120 : GENETTA IMI / DAGA VIMPI 'I am [a] girl good lovely'

While the exact meaning of the word is unknown, both Latin parallels and the very nature of inscription suggest 'girl' rather than 'daughter'.

Its insular cognates are Welsh geneth (for 'girl', while merch [< Old Celtic *merkka] was used for 'daughter') and Old Irish gen 'girl, young woman' (a rare word found in glosses only; see DIL, s.v. gen 2). 
For Welsh geneth, the general rule of spirantisation in auslaut allows us to restore its Proto-British form * genetta with a secondary gemination which might have been of expressive nature (Morris Jones 1913: 133).

The Old Irish word ingen ' 1 . girl; 2. daughter' could possibly be a secondary formation based on the same stem *gen-; however, in Middle Irish ingen $_{1}$ (for 'girl') was superseded by another word of unclear etymology, cailín (see below). Of ingen, Cormac mac Cuilennáin (see above) wrote what is consistent with this kind of etymology:

Ingen .i. in-gin .i. nī ginither üaithe. Nō in-gen .i. nī bean. Gune graece, mulier latine [Meyer 1913, \# 773]

'Ingen, i.e., non-procreative, or in-gen 'not woman'. ['Woman' is] Gune in Greek, mulier in Latin.'

The word ingen (Middle Irish iníon 'daughter', Modern Irish $N i$ of patronymics and family names) is first recorded, as INIGENA, in the inscription, what Kenneth Jackson describes as "a bilingual puzzle" (Jackson 1953: 185). However, Damian McManus is more cautious, saying that "the relationship between the Ogam and Latin is unclear" (McManus 1997: 61). Let us invoke CIIC \# 362 inscription from Wales:

\section{AVITORIA FILIA CVNIGNI - AVITTORIGES INIGENA CUNIGNI (or: INIGENA CUNIGNI AVITTORIGES)}

Arguably, the grammatical discrepancy between Irish Avitoriges (m. gen.) and Latin Auitoria (f. nom.) does not disprove the bilingual nature of the inscription, but rather reflects an attempt of an intercultural exchange that is, an imitation of the Roman praenomen-nomen-cognomen model of naming, created by a Goidel (or perhaps a Britt) and written down in Ogham. It could mean that Avitoria is both a daughter of a certain Avitorix (like the name Tullia that indicates being a daughter of Marcus Tullius) and a member of the Cunigni family. Compare another Latin inscription from the Roman Britain:

\footnotetext{
Dis M(anibus) / Verecu(n)d(a) Rufi filia cives / Dobunna annor(um) $X X X V \ldots$

'To the spirits of the departed: Verecunda, daughter of Rufus, tribeswoman of the Dobunni, aged 35' (RIB 621, see (Raybould, Sims-Williams 2007: 90)).
}

In this context, it is not unlikely that the word INIGENA in the Ogham text, seemingly matched by filia of the Latin counterpart, is in fact 
supposed to mean filia cives 'native (female) person'. Moreover, we might suggest that the Irish word, rather than deriving from Old Celtic *eni-genā 'born into a family' (compare Gaulish Enigenus (Evans 1967: 206)), is an early loanword from Latin and derives from indigena 'native/ local (female) person'. This suggestion is supported by the phonetic form of the word. According to Jackson, the vowel affection $\breve{e}>\breve{i}$ ( 'raising' caused by the $i$ of the next syllable) did not occur until the mid $-6^{\text {th }}$ century, so it postdates the apocope of the late $5^{\text {th }}$ century. Yet the inscription is basically of pre-apocope character, which suggests that the native form should have been *ENIGENA. However, dating Ogham inscriptions may be difficult because of the deliberate archaisation employed by its carvers (often in consistent and sophisticated manner). Anyway, in Goidelic, this lexeme seems to have superseded the old IE term for 'daughter'. Before the Middle Irish period, it bore a broader sense of 'daughter, girl, young woman'. Compare Welsh merch (<*merio- 'junger Mann', with the $-g$ formant and an emphatic gemination, a Lithunian cognate being mergà 'girl, maidservant' (IEW 738-39)).

\section{Lost/loan kinship terminology}

The suggestion that the Goidelic term for 'daughter' could have been a loanword may be supported by the Uralic data. For instance, in Sami the lexeme for 'daughter' is a loanword from early Baltic *tektāre; in Finnish and Estonian, the same word seems to be of Scandinavian origin (tyttär, compare Swedish dottir). The original proto-form for 'daughter' cannot be reconstructed either in Uralic or in Altaic (Koivulehto 2007 241; Sammallahti 2007 404; Rykin 2009).

What could have caused the loss of the IE term for 'daugher' in Insular Celtic, given that, as the existence of differing lexemes suggests, it happened independently in different languages and cannot be traced back to a single linguistic event (unlike the loss of the IE word for 'son' which in Proto-Celtic was * $m a k^{w} k^{w}$-os and whose etymology is problematic)?

Arguably, the simultaneous loss of the IE word for 'daugher' in more than one of the Insular Celtic languages may be explained through the fact that the Irish and the Britons had a special institution of fosterage (Old Irish altramm) - prominent families would send their children to foster-parents, which meant raising their social status. The 'baby language' words aite and muimme would then acquire the corresponding meanings of 'foster father' and 'foster mother' ("the intimate forms have been transferred to the fosterparents" (Kelly 1988: 86)); compare, however, Welsh mam 'mother, Mom' and tad 'father, Dad'. At the same time, in modern Irish dialects (in colloquial speech), the Old Irish word 
for 'foster child' (dalta) may be used for addressing one's biological child.

On the other hand, the insular Celtic loss of the IE lexemes for 'daughter' and 'son' may be regarded as fitting into the pattern of the 'linguistic revolution' which took place between the $4^{\text {th }}$ and $6^{\text {th }}$ centuries A.D. and must have had social origins - perhaps related to the conversion to Christianity. Namely, social changes caused shifts in the meanings of social terms; however, these shifts are consistent with the patterns widely observed in other languages. The semantic transition between 'girl daughter - maidservant' (or between 'boy - son - male servant') is a frequent if not universal phenomenon well-attested in many languages (Zalizniak 2008). It is most obvious in English where maid still retains a more archaic meaning of 'girl', used in poetry as recently as in the $19^{\text {th }}$ century (from Saxon magden 'girl, maidservant'; compare modern German Mädchen 'girl', derived from the same stem); boy has also an immediate meaning of 'male servant' (just as garçon in French). In Latin, puella stands for both 'girl' and 'daughter', while puer for 'child/boy' and 'servant'. Czech děvice and Polish dziewa mean 'girl', but their Sorbian cognate dźowka means 'daughter'; Czech naše holka means literally 'our girl' but is in fact used for 'daughter'; in informal Russian, devochka ('girl') may also be used for 'daughter', as an intimate form, and in colloquial Russian, dochka (the diminutive form of the word for 'daughter') is used for 'girl' as a form of address (by older people) (Trubachev 2006: 56). Notably, this semantic process is bilateral, yet the very shift occurs within a single shared semantic field, without transgressing certain boundaries.

\section{5. 'Girl' $\leftrightarrow$ 'maid-servant' as a universal semantic shifting}

Later, in the Middle Irish period, the further changes of the social structure caused changes in age-sex group stratification, which left some semantic niches empty, so that the gaps called for filling in. Thus, if in earlier Irish the word ingen could mean either 'daughter', 'girl' or 'young woman', in Middle Irish it only retained the first meaning of 'daughter', while another word for 'girl', cailín, emerged. Originally, cailín could have probably meant 'maidservant'; morphologically, it is a diminutive of the archaic word caile. The latter is masculine and of unclear etymology (LEIA-C 12). This is the way Cormac glossed it:

Caile do chaillig coimèta tighe is ainm (Meyer 1913, \# 243)

Caile comes from caillech ['old woman'], as a home warden. 
While my earlier suggestion was linking cailín to Georgian kal- 'woman', kale 'girl', or Turkic *kalin 'daughter-in-law' (Mikhailova 2007: 58), now I am inclined to dismiss this idea as speculation. My present (and perhaps just as speculative) etymology links this word (instead of linking it to caillech 'old woman' < Latin pallium 'cloak') to Old Irish cailech 'cup' (< Latin calyx 'cup'). Cailin might be a back-formation from cailech understood as an adjective (cail-ech), 'object related to maidservants'. The diminutive suffix could have been added later. This is not an uncommon way of how folk etymology works: compare suckl-ed < suckle $<$ suckling, understood as suckl-ing, a gerund (in fact, suck-ling, a noun with an archaic diminutive suffix). However, this etymology may only be hypothetical.

While Mallory and Adams have suggested, with some uncertainty, that the Proto-Indo-European word for 'daughter', *dhugh $\left(h_{2}\right)$-tor, came from *dhug- 'food' (therefore, 'daughter' = 'the one who cooks' (Mallory and Adams 1997: 148), such kind of semantic transition looks uncommon. More typical is a reverse transition (boy 'male child' $\rightarrow$ boy 'male servant', maid 'girl' $\rightarrow$ maid 'female servant'), attested in many languages (see above). Apparently, the meaning of '(unskilled) servant' or 'aid' is secondary and rooted in social reality: unskilled jobs were performed by adolescents, although the exact ways of semantic transition may have been more complicated - compare Russian words rab 'slave', roba 'female slave' [archaic], rebyonok (dialect robyonok) 'child', all of them deriving from Proto-Slavonic *orb- 'feeble', 'having no rights' (Chernykh 1994: 91, 102). There are also African examples of semantic derivation linked to age-sex groups, of which V. A. Popov wrote:

A well-known phenomenon that seems to be universal throughout social history is the extension of terms, originally meaning either children or uninitiated young people, to indicate lower-class people (slaves or other subordinates). So, as may be expected, in Akan languages the meaning of abofra 'child' shifts to 'servant, subordinate', akoa (another term for 'child') to 'slave, servant', abaawa ('young woman') to 'maidservant', abasimma (also 'young woman') to 'of lower class' etc. (my trans., Popov 1981: 95).

Nevertheless, however frequent these transitions were, they cannot be called truly universal. In Old Irish, a corresponding semantic transition 
occurred in the use of the word gilla whose original ${ }^{3}$ meaning was probably 'a male adolescent at the age when he first gets a weapon' (DIL), and this polysemy had survived until much later (Dinneen 1927: 536).

Given that Old Irish cail 'maidservant', from which the diminutive form cailín derives, cannot be reliably traced back to any IndoEuropean stem, it is not implausible that this word comes from non-IndoEuropean substrate, which allows reconstructing a possibly more complex way of its semantic evolution: the original word from the pre-Celtic substrate vocabulary could mean 'girl' and then shift to 'maidservant' - so it is at the latter stage that it was borrowed into Old Irish. Parallels are found in modern Russian which borrowed the French word garçon (both 'male child' and 'waiter) to indicate 'waiter' only, and the English word boy which in Russian narrowed to 'male native servant in former British colonies' (the meaning now near-obsolete in English); compare also the Germanism Mädchen Zimmer used in the jargon of the old St. Petersburg for 'a small room next to the kitchen, housing (female) servants'. However, the use of these loanwords in Russian is very limited (if not obsolete), and further or broader semantic evolution did not happen.

In Welsh, the semantic shift marking the divergence of 'girl' and 'daughter' must have happened earlier, or it may be the case that the extant Welsh records date from much later period, since the words merch and geneth found in surviving Middle Welsh texts do not seem to be semantically competing. Compare, however, the translation of Welsh merch (found in a $16^{\text {th }}$-century text) as maid by Morris Jones:

\section{Llyfr Ofydd a fydd i ferch}

'The maid shall have a book of Ovid' (Morris Jones 1913: 170)

Neither of these lexemes is attested in Old Welsh. Interestingly, at the same time (presumably, about the $16^{\text {th }}$ century) Old Irish macc, from a broader meaning of 'son, boy, child', changes to a narrower one of 'son', while the resulting semantic gap is filled in with the word buachaill (Breton bugel 'child'), derived from Old Irish bó caill, literally 'cowservant', i.e. 'cowboy'. That is, another uncommon semantic shift within the same frame, from 'servant' to 'child', occurs. Welsh, where the need for a specification term for 'male child' had also arisen (the older polysemantic term map being attested in a variety of meanings as early as

\footnotetext{
${ }^{3}$ In fact, there is little certainty as to which of the meanings was the earlier one. In the extant written records, the meaning of 'servant' is more frequent. One may deduce that the compilers of Irish dictionaries tend to mark it as 'derivation' automatically, by analogy with the more common type of semantic shift. Presumably, this question needs further research, especially on the word's etymology which is presently unclear.
} 
in Middle Welsh), ${ }^{4}$ used another way of semantic derivation, forming the word bachgen 'boy' from bach 'little'. The same way of semantic transition is clearly seen in modern Russian mal'chik 'boy', derived from the Old Russian adjective mal 'little [masculine form]' (now occurring as a root, rather than an independent word, but retaining the meaning of 'little').

Anyway, the shift within a semantic field mirrors social changes, in this particular case - changes of the idea of age-sex group stratification.

\section{As a conclusion: The way forward}

It seems promising to broaden the context of this research endeavour by adding the notions of 'cub' and 'small creature' and by drawing parallels from other languages, perhaps even other than Indo-European. On the other hand, the apparent and potentially productive challenge is tracing the diachrony of the 'child' concept in Irish and Welsh, observing how vocabularies subtly change within an integral semantic field and how they reflect social changes such as those of age-sex group stratification.

Institute of Linguistics, Moscow

\section{Abbreviations}

CIIC - Macalister, R.A.S., ed., 1945, Corpus Inscriptionum Insularum Celticarum, Dublin: Genprint, vol. I.

DIL - Dictionary of the Irish Language, Dublin: RIA, 1913-

IEW - Pokorny, J., 1959, Indogermanishes etymologishes Wörterbuch, Bern, München: Francke Verlag.

LEIA - Lexique étymologique de l'irlandais ancien de J. Vendryes (A Paris, CNRS, 1959, repr. Dublin : DIAS, 1981; R,S - Paris, CNRS, 1974; C - E.Bachellery et P.-Y.Lambert - Paris, DIAS-CNRS, 1987; D P.Y.Lambert. Paris, DIAS-CNRS, 1996).

RIB - Collingwood, R.G., Wright, R.P., eds., 1995, The Roman Inscriptions of Britain, I, Inscriptions on Stone, Stroud: Sutton.

RIG - Lambert, P.Y., ed., 2002, Recueil des Inscriptions Gauloises, vol. II, f. 2. Textes Gallo-Latins sur instrumentum, Paris: CNRS.

\footnotetext{
${ }^{4}$ For corresponding examples, see (Mikhailova 2007a: 14).
} 


\section{References}

Carpelan, Ch., Parpola, A. and Koskikallio, P., eds., 2007, Early Contacts between Uralic and Indo-European: Linguistic and Archaeological Considerations. Papers presented at an international symposium held at the Tvarminne Research Station of the University of Helsinki 8-10 January, 1999, Helsinki: Suomalais-Ugrilainen Seura.

Chernykh, P. J., 1994, Istoriko-etimologicheskij slovar' sovremennogo russkogo jazyka [A Historic and Etymologic Dictionary of Modern Russian], Moscow: Russkij Jazyk.

Delamarre, X., 2003, Dictionnaire de la langue gauloise. Une approche linguistique du vieux-celtique continental, Paris : éditions errance.

Dinneen, P. S., 1927, Foclóir Gaedhilge agus Béarla. An Irish-English Dictionary, Dublin: Irish Texts Society.

Evans Ellis, D., 1967, Gaulish Personal Names, Oxford: Oxford University Press.

Jackson, K., 1953, Language and History in Early Britain, Edinburgh: Edinburgh University Press.

Kelly, F., 1988, A Guide to Early Irish Law, Dublin: DIAS.

Koivulehto, J., 2007, 'The Earliest Contacts between Indo-European and Uralic Speakers in the Light of Lexical Loans', in: Ch. Carpelan, A. Parpola \& P. Koskikallio, 235-263.

Kullanda, S., 2002, 'Indo-European 'Kinship Terms' Revisited', Current Anthropology 43.1 (February), 89-111.

Lejeune, M., 1985, 'Textes gaulois et gallo-romains en cursive Latine: le plomb du Larzac', Études Celtiques 22, 95-177.

Mallory, J. P., \& Adams, D. Q., 1997, Encyclopaedia of Indo-European Culture, London: Fizroy Dearborn.

Mallory, J. P., \& Adams, D. Q., 2006, The Oxford Introduction to ProtoIndo-European and the Proto-Indo-European World, Oxford: Oxford University Press.

Matasović, R., 2009, Etymological Dictionary of Proto-Celtic, Leiden: Brill.

McManus, D., 1997, A Guide to Ogam, Maynooth: An Sagart.

Meyer, K., ed., 1913, Sanas Cormaic. An Old Irish Glossary, Dublin: (repr. 1994, Dublin: Llanerch Publishers).

Mikhailova, T. A., 2007, 'K probleme rekonstruktsii jazyka Piktov' ['Towards the Problem of Reconstructing the Language of the Picts], Studia Orientalia et Classica. Papers of the Institute of Oriental and Classical Studies, XI. Aspects of comparative linguistics 2, 53-64. 
Mikhailova, T.A., 2007a, 'Macc, Cailín and Céile - an Altaic Element in Celtic?', in: H. L. C. Tristram, ed., The Celtic Languages in Contact, Potsdam: Potsdam University Press, 4-24.

Morris Jones, J., 1913, A Welsh Grammar. Historical and Comparative. Oxford: The Clarendon Press.

Ó Corrain, D., \& Maguire, F., 1990, Irish Names, Dublin: The Lilliput Press.

O'Brien, M. 1956, 'Etymologies and Notes', Celtica 3, 168-184.

O’Brien, M., 1973, 'Old Irish Personal Names', Celtica 10, 211-236.

Popov, V. A., 1981, 'Polovozrastnaja stratifikatsia i vozrastnye klassy drevneakanskogo obschestva' ['Age-sex Groups and Age Classifiers of Old Akan Society'], Sovetskaja Etnographia [Soviet Ethnography], 19816, 89-97.

Raybould, M.E., Sims-Williams, P., eds., 2007, A Corpus of Latin Inscriptions of the Roman Empire Containing Celtic Personal Names. Aberystwyth: CMCS Publications.

Rykin, P.O., 2009, 'Semanticheskij analis terminov rodstva i svojstva v sredne-mongolskom jazike' ['Structural Analysis of the System of Kinship Terms in Middle Mongolian'], Journal of Philology. Ural-Altaic Studies 1, 80-91.

Sammallahti, P., 2007, 'The Indo-European Loanwords in Saami', in: Ch. Carpelan, A. Parpola \& P. Koskikallio, 397-415.

Sims-Williams, P., 2007, 'Common Celtic, Gallo-Brittonic and Insular Celtic', in: id., Studies on Celtic Languages before the Year 1000, Aberystwyth: CMCS Publications, 1-42.

Szemerenyi, O., 1977, Studies in the Kinship Terminology of the IndoEoropean languages, with special reference to Indian, Iranian, Greek, and Latin, Acta Iranica 16, Téhéran-Leiden: Edition Bibliothèque Pahlavi. Trubachev, O. N., 2006, Istorija slavjanskih terminov rodstva $i$ nekotoryh drevnejshih terminov obschestvennogo stroja [A History of Slavonic Kinship Terminology and a Study of Some Old Social Terms], Moscow, URSS.

Zalizniak, A. A., 2008. 'A Catalogue of Semantic Shifts: Towards a Typology of Semantic Derivation', in: Vanhove, M., ed., From Polysemy to Semantic Change. Towards a Typology of Lexical Semantic Associations, Amsterdam, 217-232. 